\section{The Common Cold}

\author{
Bennett Lorber, MD
}

$\mathbf{T}$ he common cold is the Rodney Dangerfield of infectious diseases-it gets no respect. Although it is among the most frequent and economically important of all infectious diseases, the cold is rarely discussed in medical school curricula, residency training programs, or even infectious diseases symposia.

The common cold occupies an almost unique position in infectious diseases, because everyone knows what it is from personal experience. As Supreme Court Justice Potter Stewart said about obscenity, "I know it when I see it." But, although we all know what the common cold is, it is hard to define. In most definitions it is described as an acute inflammation of the mucous membranes of the respiratory passages, particularly of the nose, sinuses, and throat, caused by viruses and characterized by sneezing, rhinorrhea, coughing, and so forth.

\section{HISTORY}

Colds have been well known since antiquity, but current understanding really began in 1914 when Dr. Kruse in Germany showed that nasal secretions from persons with colds could be made bacteria-free by filtration, and that these filtrates could be inoculated into the noses of recipients and cause colds. ${ }^{1}$ He thus provided direct evidence of the infectious nature of colds prior to the first isolation of a respiratory virus. These initial experiments were refined by Andrewes and Tyrrell at the Harvard Hospital in Salisbury, England. ${ }^{2.3}$ The Harvard Hospital was a prefabricated hospital planned, constructed, and shipped to England by Harvard University and the American Red Cross early in World War II "to help in the study of the epidemic disease that it was expected to follow intensive air attack." Mercifully, epidemics did not occur, and it became a military hospital. At the end of the war it was given to the Ministry of Health, and around 1946 it became the Common Cold Unit of the Medical Research Council. There,

From the Section of Infectious Diseases, Temple University School of Medicine and Hospital, Philadelphia, Pennsyluania.

Dr. Lorber is a Thomas M. Durant Professor of Medicine.

Address correspondence and reprint requests to Dr. Lorber: Section of Infectious Diseases, Temple University Hospital. Broad and Ontario Streets. Philadelphia, PA 19140. over the next 30 years, Drs. Andrewes and Tyrrell performed many important studies on cold transmission. For example, they showed that filtered nasal washings from subjects with colds could be diluted 100 -fold and still produce disease; but only about $60 \%$ of those inoculated developed symptoms. Remember, because viruses had not yet been isolated, recipients could not be screened for immunity.

In the 1940s Wade Hampton Frost along with Gover studied the seasonal incidence of colds in six large American cities, and concluded that, during the season of high prevalence (September to March), colds occurred as a series of distinct epidemics, each of several weeks duration, suggesting multiple etiologic agents. Another epidemiologic study was conducted in the 1950 s by Dingle in the so-called Cleveland Family Study. Again, he showed the seasonal nature of colds and that children had the highest annual infection rates and were the most important reservoir for cold viruses.

In the 1950s cell culture methods were used in the study of respiratory disease, and in 1956 and 1957 Pelon and Price isolated the first cold viruses. ${ }^{1}$

In the 1970s investigators at the University of Virginia and the University of Wisconsin led by Drs. Jack Gwaltney and Elliott Dick, respectively, defined the modes of cold transmission; and more recently, Hayden, Hendley, and Gwaltney at the University of Virginia have investigated the pathogenesis as well as the treatment and prevention of colds.

\section{HOW COMMON IS THE COMMON COLD?}

Young children typically have five to seven or more respiratory illnesses per year. The rate may be doubled in those in day care. The frequency of colds decreases with age, and in those under school age, boys have more colds than girls, but later respiratory illnesses are more common in women, particularly during childbearing years.

Colds are one of the most common human infections. During the first year of life, children have about 1.2 rhinovirus colds per year, and young adults have close to 1 rhinovirus cold per year. Several studies in households indicate that infection with viral replication and shedding may occur without symptoms, but $70 \%$ to $90 \%$ of transmitted infections are symptomatic. ${ }^{4}$

Colds are virtually never fatal and rarely are compli- 
cated by more serious infections, but they exact a tremendous toll in morbidity and economic cost (Table 1). ${ }^{5}$

\section{EPIDEMIOLOGY}

Colds occur worldwide, and antigenic types appear to circulate randomly. Colds begin in early childhood and occur throughout life, with illness being most common in young children, but with peak antibody prevalence seen in young adults, then declining with advancing age. In temperate climates, colds peak in the fall and again in the spring months.

\section{WHAT CAUSES COLDS?}

The agents responsible for colds are indicated in Table 2. Rhinoviruses (rhino for nose) are the most important causes and account for $30 \%$ to $40 \%$ of all colds. Rhinovirus colds occur in the fall and the spring. Another important cause of colds are the coronaviruses, which are most prevalent during winter months.

In the Tecumseh Studies, Monto and his Michigan colleagues studied respiratory infections in two 5-year periods, first in family groups and later in the community, 6,7 They found that rhinoviruses were the single most important cause of colds, accounting for more than a third. In one 5-year period, 52 of the then-known 89 rhinovirus serotypes were seen. Colds were most frequent in those less than 5 years of age, and the median symptom duration in adults was approximately 3 weeks. They noted that cold transmission intensified in September and again in May, but occurred year-round in oscillating outbreaks.

Rhinoviruses are members of the Picornaviridae family (pico for little-RNA), Other members of the family include enteroviruses like poliovirus and hepatitis A virus. Rhinoviruses are single-stranded RNA viruses of 20 to 27 $\mathrm{nm}$, without an envelope. They replicate well at $33^{\circ}$ to $35^{\circ} \mathrm{C}$ but poorly at $37^{\circ} \mathrm{C}$, which probably accounts for the fact that these viruses cause upper respiratory tract infections and not pneumonias. As there are approximately 100 antigenically distinct types of rhinoviruses, one could have a cold a year for life and never run out of new ones. Rhinoviruses are hardy and remain infectious for at least

Table 1. The Cost of Colds Annually in United States

\begin{tabular}{lc}
\hline No. of colds & 100 million \\
Days of restricted activity & 250 million \\
Visits to physicians & 22 million \\
Lost days of work & 30 million \\
Lost days of school & 30 million \\
Economic burden & 5 billion dollars \\
In cold remedy sales & 1 billion dollars \\
In analgesic sales & 1.5 billion dollars \\
\hline
\end{tabular}

*Adapted from reference 5 .
Table 2. Causes of the Common Cold*

$\left.\begin{array}{lcc}\hline \hline \text { Cause } & \begin{array}{c}\text { No. of } \\ \text { Antigenic } \\ \text { Types }\end{array} & \begin{array}{c}\% \text { of } \\ \text { Cases }\end{array} \\ \hline \text { Rhinovirus } & 100 & 30-40 \\ \text { Coronavirus } & 4 & 10-15 \\ \text { Respiratory syncytial virus } & 2 \\ \text { Adenovirus } & 47 \\ \text { Parainfluenza virus } & 4 \\ \text { Influenza virus } & 3\end{array}\right\}$

${ }^{*}$ Adapted from references 4.6 , and 7 .

three hours after drying on hard surfaces such as stainless steel or formica, but do not last as long on porous surfaces like paper tissues.

Rhinoviruses are known to infect humans, chimpanzees, and gibbons. Jane Goodall has described cold outbreaks and their seasonal pattern in her chimpanzee studies.

Research has been hindered by the fact that an inexpensive animal model of the common cold is not available. Dr. Andrewes, on his "windswept hilltop just outside Salisbury in Southern England," failed in his attempts to infect a variety of animals including mice, rats, guinea pigs, hedgehogs, ferrets, kittens, pigs, monkeys, and baboons. ${ }^{3}$

\section{PATHOGENESIS}

Rhinoviruses grow in the upper airway and attach and gain entry to host cells by binding to an intercellular adhesion molecule, so-called ICAM-1, as a receptor. The viral region that attaches to ICAM-1 is in a cleft or canyon on the viral shell. 8.9

Evidence indicates that infection begins in the adenoidal area and rapidly spreads to the ciliated epithelium in the nose. ${ }^{10}$ The frequency of large airway involvement remains unknown.

In spite of everything my mother believes (father too), drafts, cold temperature, and dampness have nothing to do with cold acquisition or severity. Andrewes addressed this question more than 40 years ago, and an excerpt from one of his papers is most instructive:

We took three groups of six volunteers. Three pairs received a dose of virus so diluted that we expected it to produce only a few colds. Three pairs were chilled; they soaked in hot baths and then stood about undried in bathing dresses in a passage for a half hour or as long as they could bear it. In addition. they wore wet socks for some hours. Most showed a drop of several degrees in body temperature, and felt rather chilly and unhappy for a time. Finally. three other pairs received the dilute virus and the chilling treatment. The results were encouraging. Chilling alone produced no colds. Dilute virus produced mild colds in two subjects, and the combined treatments, colds in four. of which two were rather good ones. We were foolish enough to repeat this experiment 
with a contrary result. Again, chilling alone did nothing but those with virus alone had on this occasion twice as many colds as those having the chilling treatment in addition to virus. So we have got to find a better technique for lowering resistance or else join the school of thought that dismisses the effects of draughts and wet socks as mere superstitions. ${ }^{3}$

Douglas and associates tried this again in the United States, and reported their results in the New England Journal of Medicine in October 1968. "I In these studies, subjects were exposed in a $4^{\circ} \mathrm{C}$ room and were seated in a $32^{\circ} \mathrm{C}$ water bath. This was done at the time of inoculation, during incubation, during maximal illness, and during recovery. There was no difference in infection rates, illness severity, viral shedding, or antibody response in subjects compared with controls.

Tiny amounts of virus will cause disease, and just one tenth of a tissue culture infecting dose ${ }_{50}\left(\mathrm{TCID}_{50}\right)$ can cause illness. Virus is shed from the nose 24 hours after inoculation, and shedding peaks on the second and third day with large amounts of virus recoverable. Nasal biopsy studies show epithelial damage is slight with little or no inflammation; cuboidal epithelial cells and some neutrophils are shed in these nasal secretions.

Several studies have examined the role of stress to see if colds are more frequent or more severe in those undergoing stress. One such study, reported in the New England Journal of Medicine in 1991, used experimental nasal inoculation in volunteers after they completed stress evaluation questionnaries. ${ }^{12}$ The authors of this study found an increase in both infection rates and symptomatic colds with increases in psychological stress. This study controlled for age, gender, education, allergic status, season, antibodies, smoking, alcohol, exercise, and other factors. In another inoculation study conducted at Stony Brook and reported the following year, infection rates were the same, but clinical colds occurred more often in subjects with a higher number of "life events" in the previous year. ${ }^{13}$

Nasal biopsy studies have shown little, if any, cell damage or inflammatory infiltrate. ${ }^{14}$ Therefore recent studies have examined the role of chemical mediators in the pathogenesis of the common cold. Kinins, prostaglandins, histamine, interleukins 1, 6, and 8, as well as tumor necrosis factor (TNF) have all been implicated as potential contributors to cold symptoms. For example, high levels of the potent vasoactive peptide bradykinin have been found in nasal secretions of subjects with symptoms but not in those shedding virus without symptoms. ${ }^{15,} 16$

In a recent study volunteers were inoculated with a rhinovirus, and nasal lavage specimens were examined daily to measure levels of interleukin 1 (IL-1), kinins, and albumin. ${ }^{17}$ Results showed that 24 hours after nasal inoculation there is a striking increase in each of these followed by rapid declines over the next 48 hours. IL- 1 levels were not significantly increased in subjects who were infected but asymptomatic, as had previously been shown for kinins. IL-1 can increase the responsiveness of some cells to bradykinin by up-regulating the expression of kinin receptors. IL-1 increases vascular permeability, and therefore could lead to increased plasma transudation and a consequential increase in albumin in nasal secretions.

Another recently reported study of natural colds occurring in children in day care showed an increase in nasal secretion levels of IL-1, IL-6, and IL- 8 as well as TNF levels associated with symptomatic colds. ${ }^{18}$ There were no differences in cytokine responses in this study in children who did or did not receive antibiotics. Levels of TNF remained elevated for a much longer period than did the interleukin levels.

\section{HOW DO WE CATCH COLDS?}

Three major routes by which a virus could get from one person to another have been extensively studied. ${ }^{19,} 20$ These are airborne transmission by small aerosolized particles, the so-called droplet nuclei, which may remain suspended for prolonged periods of time and travel significant distances; transmission by large aerosol particles that travel no more than a few feet; and direct contact. Most of the data we have regarding transmission of colds come from experimental infection rather than natural infection and may not completely reflect what happens in the real world, but are probably a good, if not perfect, approximation.

Drs. Gwaltney, Hendley, and colleagues at the University of Virginia have done beautiful studies of cold transmission. One study reported in 1978 addressed the three potential routes. ${ }^{21}$ First they demonstrated that the virus could easily be transferred from contaminated hands of one person to another. A 10-second hand contact led to viral transfer in 20 of 28 contacts. They then demonstrated that hand-to-hand contact was an efficient method of cold transmission whereas large-particle aerosols rarely transmitted infection and small-particle aerosols were ineffective in transmitting colds (Table 3 ).

Employing a clever device that enables volunteers to sit at a table and play cards while prohibiting them from touching their noses. Dr. Elliott Dick and his University of Wisconsin colleagues have demonstrated that colds can be transmitted by large-particle aerosol. ${ }^{22}$ However, this means of transmission is not efficient and requires prolonged exposure unlikely to occur in most natural settings. ${ }^{23 .} 24$ Transmission by this route also appears to re-

Table 3. Transmissibility of Experimental Colds*

\begin{tabular}{lcc}
\hline \hline Method & Exposed & Infected \\
\hline Hand-to-hand & 15 & 11 \\
Large-particle aerosol & 12 & 1 \\
Small-particle aerosol & 10 & 0 \\
\hline
\end{tabular}

*Adapted from reference 21 . 
quire the presence of severe colds with cough as a prominent symptom. Tyrrell showed in the 1960 s that infectious aerosols produced by coughing and sneezing come primarily from the salivary pool in the mouth and not from nasal secretions.

Studies of the risk of infection by site of initial inoculation show that the amount of virus needed to produce symptomatic infection following inoculation onto the nasal mucosa or inside the nares is $1 / 10,000$ th the amount necessary following inoculation on the nose outside of the nares. ${ }^{23}$ Other studies have shown the conjunctiva to be a hospitable place for rhinoviruses, with transmission efficiencies approximating those of the nasal mocusa. Rhinovirus infection is not believed to occur in conjunctival cells; rather, virus deposited in the eye is rapidly passed down the tear duct into the nasal passages. The mouth is not an efficient place for transmission, as has been demonstrated by kissing studies. In 1984, the Wisconsin group reported a study in which donors kissed recipients for $1 \frac{1}{2}$ minutes (two 45 -second contacts). ${ }^{23}$ Subjects were instructed to "use the kissing technique most natural to them." Only $8 \%$ of those kissed by infected donors got symptomatic colds.

Studies of the natural rate of secondary infection have shown transmission efficiencies ranging from $38 \%$ in spouses in studies of married couples to as high as $88 \%$ in persons confined to a small closed environment in Antarctica. $^{25}$ The incubation period for secondary cases in households has been shown to be 1 to 10 days with a median of 3 days. ${ }^{26}$

Virus has been found on $40 \%$ of donor hands on a single sampling and $90 \%$ on repeat sampling. It is found in only $10 \%$ of cough or sneeze samples. It survives on the hands even when dry for several hours. ${ }^{27}$

So it appears that the major means of cold transmission is from the donor's nose to the donor's hand, and from there to the recipient's hand, and hence from the recipient's finger to his or her nose or eye. Fomites can transmit colds. If a donor touches a cup handle or playing cards and then leaves the room, an individual who subsequently handles these objects may develop a cold.

The question of how often we place ourselves at risk for colds by putting our fingers to our noses or rubbing our eyes has been answered by the Virginia group who observed medical staff attending grand rounds presentations as well as individuals in a Sunday School group. ${ }^{28}$ The doctors rubbed their eyes and picked their noses about once every two to three hours; Sunday School attendees seated in a circle rubbed their eyes with equal frequency but less often touched their fingers to their noses.

\section{IMMUNITY}

Even if immunity were complete, one could have a cold every year and not use up all the antigenically distinct rhinoviruses. Neutralizing antibodies to rhinoviruses are found in the serum of only $40 \%$ to $85 \%$ of individuals with symptomatic infection depending on the type of virus. Immunity to coronaviruses appears to be short-lived, and reinfections with the same immunotype do occur. Virtually nothing is known about the role of cellular immunity in colds. However, there is evidence that rhinovirus colds trigger a systemic cell-mediated response. ${ }^{29,} 30$

\section{DIAGNOSIS}

The diagnosis of a cold is not difficult-you know it when you see it. The virus can be cultured on human embryonic lung cell lines such as WI-38, but this is rarely done outside of investigational studies. Serology is not useful because there are too many serotypes and symptomatic individuals do not always demonstrate a rise in antibody titer.

\section{CLINICAL FEATURES}

The common clinical features of the common cold are shown in Table 4. Nasal symptoms including nasal stuffiness, runny nose, and sneezing are the most common symptoms, occurring in $45 \%$ to $75 \%$ of patients. Scratchy or sore throats are the next most common, occurring in one third to one half of patients, and constitutional symptoms such as headache, feverishness, and myalgia are less frequent, occurring in $10 \%$ to $40 \%$ of patients. A third of patients experience cough or hoarseness or both. Symptoms tend to peak on the second or third day of ill ness, and most symptoms resolve in roughly one week with the exception of cough, which may linger. Smokers have the same incidence of colds as nonsmokers, but the symptoms are more severe, particularly cough.

\section{COMPLICATIONS}

Complications of colds are uncommon. Clinical sinusitis is seen in $0.5 \%$ of children with colds and otitis media in $2 \%$. Rhinoviruses appear to interfere with the effectiveness of antimicrobial therapy for bacterial otitis media

Table 4. Clinical Features of the Common Cold

\begin{tabular}{lc}
\hline Symptom or Sign & $\%$ \\
\hline Nasal & \\
Discharge & 75 \\
Sneezing & 60 \\
Obstruction & 45 \\
Pharyngeal & \\
Sore throat & 50 \\
Scratchy throat & 30 \\
Lower respiratory & \\
Cough & 40 \\
Hoarseness & 30 \\
Constitutional & \\
Headache & 40 \\
Feverishness & 15 \\
Myalgia & 15 \\
\hline
\end{tabular}


more than other viruses. ${ }^{31}$ In adults, natural rhinovirus colds are frequently associated with pronounced but transient increases in middle ear pressure. ${ }^{32}$

Cold viruses have been shown to precipitate asthma attacks, and in children have been the most common infectious agents associated with acute attacks. In experimental rhinovirus infection, forced expiratory volume in one second $\left(\mathrm{FEV}_{1}\right)$ is decreased, and some adults with mild to moderate asthma have been shown to have an increase in histamine sensitivity during rhinovirus infection. Most exacerbations of chronic obstructive pulmonary disease are linked to viral rather than bacterial infections; rhinoviruses can contribute to this morbidity, but less frequently than other respiratory viruses.

Although the percentage of colds that are complicated (sinus, ear, asthma, bronchitis), the absolute number of cases of the complications is large because colds themselves are so common.

Recently published studies of computed tomographic imaging, ${ }^{33}$ as well as magnetic resonance imaging,, ${ }^{34}$ in patients with uncomplicated colds have shown that sinus abnormalities are extremely common and self-limited. A cold is in reality a rhinosinusitis. The frequency of sinus abnormality should not be used as a rationale for antibiotic treatment of colds, as some have suggested, because these studies show that sinus involvement is common and self-limited.

\section{TREATMENT}

There is a great deal of irrational behavior regarding cold treatment. In Dr. Andrewes' words, “almost everyone has his own foolproof technique for preventing or curing colds ... even the most eminent men of science almost invariably lose all sense of critical judgment when colds and especially their own colds are concerned." The great physician-educator, Sir William Osler, did not think much of the cold remedies of his day, and his own recommendation for cold management is as follows: Go to bed. Hang your hat on a bedpost. Drink whiskey until you see two hats. In the morning you'll be much better.

For the moment, cold treatment is primarily symptomatic. There is no role for antibiotics in the typical cold. Direct approaches to the virus include blocking agents to prevent the virus from binding to ICAM-1 or to give soluble ICAM-1 to bind virus before it reaches receptors. Agents such as these are under investigation, ${ }^{35}$ but none are available.

Antiviral medications have been studied including interferon and other agents. Interferon does work. Studies comparing interferon alfa with placebo show that interferon-treated subjects have a diminished rate and duration of virus shedding and decreased nasal secretion weights during the period of drug administration. ${ }^{36}$ The problem with interferon alfa is that many subjects experience local adverse effects including nasal dryness, crusting, bleeding, and mucosal ulceration. ${ }^{37,38}$
A number of direct antiviral agents have shown good ability to inactivate rhinovirus in vitro. One such agent, pirodavir, was studied in a randomized double-blind placebo-controlled trial ${ }^{39}$ Those treated with intranasal pirodavir had less virus recoverable from nasal washes, but unfortunately there was absolutely no impact of the antiviral on any of the usual cold symptoms compared with those of placebo-treated patients.

Another approach to treatment employs antimediators because there is good evidence implicating kinins, cytokines, and so forth, in pathogenesis of colds. To summarize, data for these agents are not compelling, and often conflicting. Agents that have been studied include aspirin and other nonsteroidal anti-inflammatory agents, both nasal and systemic steroids, antihistamines, and ipratropium, a parasympathetic blocking agent.

In some studies, aspirin was shown to be better than placebo in decreasing cold symptoms, but one should view these results with caution since the major effect of aspirin and nonsteroidal drugs is on headache and sore throat and not on the nasal symptoms. In some studies aspirin and other nonsteroidal drugs increase viral shedding when compared with placebo. ${ }^{40}$ Symptomatic improvement coupled with prolonged shedding could be bad in terms of the public health because patients who feel better are more likely to return to work or school and, while shedding virus for a longer time, spread the infection to a greater number of individuals. In 1992 the Virginia group reported on the use of naproxen in experimental colds, finding no alteration of viral shedding or antibody responses but a beneficial effect on headache, malaise, myalgia, and interestingly, cough. ${ }^{41}$ There was no effect on nasal symptoms. Nonsteroidal drugs are prostaglandin inhibitors, and it has been shown that intranasal challenge with prostaglandin is a potent stimulus for cough in healthy volunteers.

In a recent study of intranasal and systemic steroids (inhibitors of IL-1 production) before and after inoculation with virus, the steroid-treated group shed virus for a longer period than those receiving placebo, but there was no difference in infection rates. ${ }^{42}$ These data and those from earlier studies showing that patients on steroids do not seem to have worse colds or more complications are comforting because many individuals use nasal steroids for seasonal allergies.

Data on antihistamines are also conflicting. Chlorpheniramine was superior to placebo in a multicenter trial. ${ }^{43}$ Studies of terfenadine showed no benefit. ${ }^{44 .} 45 \mathrm{~A}$ more recent study employing the antihistamine clemastine fumarate, which has anticholinergic and $\mathrm{H} 1$ blocking actions, showed a $35 \%$ to $50 \%$ reduction in sneezing and nasal discharge without impact on other symptoms including nasal obstruction, sore throat, cough, headache, and malaise. 46

The nasal secretions of colds have been reduced by using nasal ipratropium, a parasympatholytic agent. ${ }^{47}$ Vasoconstrictors such as phenylphrine, ephedrine, or oxy- 
metazoline in the form of drops or spray do provide symptomatic relief of obstruction, but the relief is short-lived, and after a couple of days use rebound is a problem. ${ }^{48} \mathrm{~A}$ combination of antihistamine plus pseudoephedrine was reportedly effective. ${ }^{49}$ Gwaltney has recommended a multipleagent approach, combining an antiviral agent with other compounds that block selected inflammatory pathways. ${ }^{50}$

There is a common belief that milk produces mucus. An Australian study showed that milk did not produce higher levels of nasal secretions during rhinovirus infection. ${ }^{51}$ Tonsillectomy does not decrease the incidence of colds.

Other treatment approaches include inhalation of warm moist heat (chicken soup equivalent), along with zinc and vitamin $\mathrm{C}$. Studies have both supported the efficacy of these remedies and shown no beneficial effect. Ty, rell at the Harvard Hospital showed that nasal hyperthermia, in the form of inhaled moist heat when used at the beginning of a cold, reduced symptoms by more than $40 \%{ }^{52}$ More recent studies from the Cleveland Clinic in patients with natural colds showed that raising intranasal temperature to $43^{\circ} \mathrm{C}$ by steam inhalation was no better than placebo with regard to nasal congestion, drainage, sneezing, and nasal resistance. ${ }^{53.54}$

There was some early enthusiasm for zinc gluconate (zinc inhibits viral polypeptide cleavage). Two randomized controlled trials of zinc gluconate lozenges taste-matched with placebo (unlike earlier studies) were performed by the Virginia group in the late 1980s and showed no efficacy. ${ }^{55}$ A similar negative result with zine acetate was reported from Australia; in fact, illness lasted longer in the zinc-treated group. ${ }^{56}$ A 1992 study of zinc gluconate from the Dartmouth College Health Service showed a $50 \%$ reduction in the duration of symptoms if the medication was started within one day of the onset of symptoms; taste-matching was not optimal in this study. ${ }^{57}$

There is no clear therapeutic effect of vitamin C. ${ }^{58}$ Regarding treatment, the late, renowned sportscaster Red Barber, when asked one day in 1986 if he had any remedies for the cold, said: "The best treatment I know for a cold is a pair of clean sheets." Or as the old adage says: With proper treatment a cold can be ended in seven days; otherwise, it lasts a week. These statements are unduly pessimistic. Some standard remedies do seem to give relief. Among these are decongestants (oral preferred) for nasal obstruction, dextromethophan and codeine (possible naproxen and ibuprofen) for cough, first-generation antihistamines for reducing sneezing and rhinorrhea, warm gargles for sore throat, nonsteroidal anti-inflammatory drugs for headache and sore throat, and petrolatumbased ointments for raw and macerated skin around the nose and upper lip.

\section{PREVENTION}

Vaccines are not likely to be useful, as there are more than 100 antigenically distinct rhinoviruses, several coronaviruses, 47 adenoviruses, and so on.
Interferon and, before that, interferon inducers have been shown to prevent colds in home contacts. An early study used intranasal poly-I:C, an inducer of interferon, with beneficial effects, ${ }^{59}$ In later studies, postexposure prophylaxis with interferon alfa reduced respiratory infection by $40 \%$ and almost eliminated colds due to rhinoviruses. ${ }^{60.61}$ Long-term interferon use caused much nasal irritation and produced bloody discharge and nasal ulcerations, ${ }^{37,38}$ but short-term use (5 days of prophylaxis) would probably be sufficient and would avoid local side effects. In another postexposure study in families employing intranasal interferon alfa-2b, no benefit was seen. ${ }^{62}$ Interferon beta is as active in vitro as interferon alfa and appeared to be better tolerated. Unfortunately, in a study of natural colds in early autumn, colds occurred in $5 \%$ of the placebo-treated group and $6 \%$ of those receiving interferon beta. ${ }^{63}$

Unfortunately, Linus Pauling notwithstanding, the weight of the evidence is that vitamin $C$ is minimally helpful, if at all, in the prevention of colds. ${ }^{64}$ Many studies of vitamin $\mathrm{C}$ suffer from a placebo effect since subjects taking vitamin $\mathrm{C}$ were able to detect the bitter taste. Coulehan and colleagues showed a beneficial effect of vitamin $C$ prophylaxis in a Navajo boarding school. ${ }^{65}$ Those taking vitamin $\mathrm{C}$ prophylaxis had fewer days of respiratory infection morbidity. Disappointingly, 2 years later, the same group performed a double-blind, placebo-controlled study of vitamin $\mathrm{C}$ prophylaxis in Navajo school children in which no benefit was shown. ${ }^{66}$ In fact, children with high blood levels of vitamin $\mathrm{C}$ had a longer mean duration of illness than others.

What can work to prevent colds are efforts to block transmission. Paper tissues do decrease cold transmission, especially if impregnated with a virucidal agent. ${ }^{67,68}$ But even without such agents, tissues mechanically block virus transmission if used and disposed of promptly after use. Studies in households show that mothers of children with colds did not catch colds if they dipped their hands in virucidal baths. Rates were reduced from 40 to 13 colds per 1,000 days of exposure. Iodine in a $2 \%$ solution is highly effective but stains the skin. A 1984 publication showed that a lotion containing glutaric acid worked for some, but not all, strains of rhinoviruses. ${ }^{69}$

Handwashing is a good idea, as is remembering to keep one's fingers away from the eyes and nose.

Finally, the great humorist Robert Benchely provided some advice about avoiding colds in a 1947 essay. I'd like to share some of his wisdom.

Don't breathe through your mouth or your nose. These two orifices have been called "the twin roads to germville" and, on a busy day, present a picture to the microscope similar to that of the Boston Tumpike. So long as people use their mouths and their noses to breathe through, we're going to have epidemics, plagues and the eventual disintegration of the human race.

Eat a balanced diet. No proteins. no starches, no carbohydrates. Just a good steak with lyonnaise pota- 
toes and asparagus. Remember the old adage: "Stuff a cold and stuff a fever."

No exercise. This is all-important. Exercise just stirs up the poisons in the system and makes you a hot-bed of disease. Sit, or lie. as still as possible.

If you think you have caught a cold, call in a good doctor. Call in three good doctors and play bridge. ${ }^{70}$

\section{REFERENCES}

1. Gwaltney JM Jr. Historical eras of the common cold. In: Root RK. Sande MA, eds. Viral Infections: Diagnosis, Treatment and Prevention. New York: Churchill Livingstone, 1993:1-13.

2. Jackson GG. The Medical Research Council Common Cold Unit. Harvard Hospital, Salisbury, Wilts, England. Rev Infect Dis. 1989: 11:1020-1.

3. Andrewes $\mathrm{CH}$. Adventures among viruses: III. The puzzle of the common cold, Rev Infect Dis. 1989;1 1:1022-8.

4. Gwaltney JM Jr. The common cold. In: Mandell GL, Bennett JE. Dolin R, eds. Principles and Practice of Infectious Diseases, 4th ed. New York: Churchill Livingstone, 1995:561-6.

5. Couch RB. The common cold: control? J Infect Dis. 1984:150:167 73.

6. Monto AS. Ullman BM. Acute respiratory illness in an American community: the Tecumseh study. JAMA. 1974;227:164-9.

7. Monto AS, Bryan ER, Ohmit $S$. Rhinovirus infections in Tecumseh, Michigan: frequency of illness and number of serotypes. J Infect Dis. 1987:156:43-9.

8. Rossmann MG, Arnold E, Erickson JW, et al. Structure of a human common cold virus and functional relationship to other picornaviruses. Nature. 1985;317:145-53.

9. Smith TJ, Kremer MJ, Luo M, et al. The site of attachment in human rhinovirus 14 for antiviral agents that inhabit uncoating. Science. 1986;133:1286-93.

10. Winther B, Gwaltney JM Jr, Mygind N. Sites of rhinovirus recovery after point inoculation of the upper arway. JAMA. 1986; 156: 1763.

11. Douglas RG Jr, Lindgren KM, Couch RB. Exposure to cold environment and rhinovirus common cold. Failure to demonstrate effect. N Engl J Med. 1968;279:742-7.

12. Cohen S, Tyrrell DA, Smith AP. Psychological stress and susceptibility to the common cold. N Engl J Med. 1991:325:606-12.

13. Stone AA. Bovbjerg DH, Neale JM, et al. Development of common cold symptoms following experimental rhinovirus infection is related to prior stressful life event. Beh Med. 1992;18:115-20.

14. Winther $B$. Effects on the nasal mucosa of upper respiratory viruses (common cold). Danish Med Bull. 1994;41:193-204.

15. Naclerio RM, Proud D, Lichtenstein LM, et al. Kinins are generated during experimental rhinovirus colds. J Infect Dis. 1988; 157:13342.

16. Proud D. Naclerio RM, Gwaltney JM Jr., Hendley JO. Kinins are generated in nasal secretions during natural rhinovirus colds. $J$ Infect Dis. 1990;161:120-3.

17. Proud D, Gwaltney JM Jr, Hendley JO, Dinarello CA, Gillis S Schleimer RP. Increased levels of interleukin- 1 are detected in na sal secretions of volunteers during experimental thinovirus colds. J Infect Dis. 1994:169:1007-13.

18. Noah $\mathrm{T}$, Henderson $F W$, Wortman JA, et al. Nasal cytokine pro duction in viral acute respiratory infection of childhood. J Infect Dis. 1995:171:584-92.

19. Gwaltney $J M J r$. Hendley JO. Rhinovirus transmission. One if by air. two if by hand. Am $J$ Epidemiol. 1978;107:357-61.

20. Hendley JO. Gwaltney JM Jr. Mechanisms of transmission of rhinovirus infections. Epidemiol Rev. 1988; 10:242-58.

21. Gwaltney JM Jr. Moskalski PB, Hendley JO. Hand-to-hand transmission of rhinovirus colds. Ann Intern Med. 1978:88:463-7.

22. Dick EC, Jennings LC, Mink KA, Wartgow CD, Inhorn SL. Aerosol transmission of rhinovirus colds. J Infect Dis. 1987:156:442-8.

23. D'Alessio DJ, Meschievitz CK, Peterson JA, Dick CR, Dick EC. Short-duration exposure and the transmission of rhinovirus colds. J Infect Dis. 1984:150:189-94.

24. Meschievitz $C K$. Schultz SB, Dick EC. A model for obtaining predictable natural transmission of rhinoviruses in human volunteers. J Infect Dis. 1984;150:195-200.

25. Warshauer DM, Dick EC, Mandel AD, Flynn TC. Jerde RS. Rhinovirus infections in an isolated Antarctic station: transmission of the viruses and susceptibility of the population. Am $\mathrm{J}$ Epidemiol. $1989 ; 129: 319-40$.

26. Foy HM. Cooney MK. Hall C, Malmgren J. Fox JP. Case-to-case intervals of rhinovirus and influenza virus infections in households. J Infect Dis. 1988; 157:180-2.

27. Ansari SA, Springthorpe VS, Sattar JA. Rivard S, Rahman M. Potential role of hands in the spread of respiratory viral infections: studies with human parainfluenza virus 3 and rhinovirus $14 . \mathrm{J}$ Clin Microbiol, 1991;29:2115-9

28. Hendley JO, Wenzel RP, Gwaltney JM Jr. Transmission of rhinovirus colds by self-inoculation. $N$ Engl $J$ Med. 1973;288:1361-4.

29. Levandowski RA, Ou DW, Jackson GG. Acute-phase decrease of $T$ lymphocyte subsets in rhinovirus infection. $J$ Infect Dis. 1986; 153:743-8.

30. Hsia J. Goldstein AL. Simon GL. Sztein M, Hayden FG. Peripheral blood mononuclear cell interleukin-2 and interferon-gamma production, cytotoxicity, and antigen-stimulated blastogenesis during experimental thinovirus infection. J Infect Dis. 1990;162:591-7.

31. Sung BS. Chonmaitree T, Broemeling LD, et al Association of rhi novirus infection with poor bacteriologic outcome of bacterial-viral otitis media. Clin Infect Dis. 1993;17:38-42.

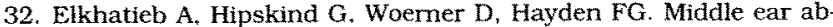
normalities during natural rhinovirus colds in adults. J Infect Dis. 1993;168:618-21.

33. Gwaltney JM Jr, Phillips CD, Miller RD, Riker DK. Computed tomographic study of the common cold. $N$ Engl $J$ Med. 1994;330. 25-30.

34. Turner BW, Cail WS. Hendley JO, et al. Physiologic abnormalities in the paranasal sinuses during experimental rhinovirus colds. I Allergy Clin Immunol. 1992:90:474-8.

35. Al-Nakib W. Tyrrell DA. Drugs against rhinoviruses. J Antimicrob Chemother. 1992:30:1 15-7.

36. Hayden FG. Gwaltney JM Jr. Intranasal interferon-alpha 2 treatment of experimental rhinoviral colds. $J$ Infect Dis. 1984; 150:174 80.

37. Samo TC, Greenberg SB, Couch RB, et al. Efficacy and tolerance of intranasally applied recombinant leukocyte $A$ interferon in normal volunteers. J Infect Dis. 1983; 148:535 42.

38. Farr BM, Gwaltney JM Jr, Adams K, Hayden FG. Intranasal interferon-alpha 2 for prevention of natural rhinovirus colds. Antimicrob Agents Chemother. 1984:26:31-4.

39. Hayden FG. Hipskind GJ, Woerner DH, et al. Intranasal pirodavir (R77. 975) treatment of rhinovirus colds. Antimicrob Agents Chemother 1995:39:290-4

40. Graham NMH. Burell CJ, Douglas RM, Debelle P. Davies L. Adverse effects of aspirin, acetaminophen, and ibuprofen on immune function, viral shedding. and clinical status in rhinovirus-infected volunteers. $J$ Infect Dis. 1990;162:1277-82

41. Sperber SJ, Hendley JO. Hayden FG, Riker DK, Sorrentino JV Gwaltney JM Jr. Effects of naproxen on experimental rhinovirus colds: a randomized, double-blind, controlled trial. Ann Intern Med. 1992;117:37-41

42. Farr BM, Gwaltney JM Jr, Handley JO, et al. A randomized controlled trial of glucocorticoid prophylaxis against experimental rhinovirus infection. $J$ Infect Dis. $1990 ; 162: 1173-7$.

43. Howard JC Jr. Kantner TR, Lilienfield LS, et al. Effectiveness of antihistamines in the symptomatic management of the common cold. JAMA. 1979:242:2414-7.

44. Gaffey MJ, Kaiser DL. Hayden FG. Ineffectiveness of oral terfena- 
dine in natural colds: evidence against histamine as a mediator of common cold symptoms. Pediatr Infect Dis J. 1988;7:223-8.

45. Berkowitz RB. Tinkelman DG. Evaluation of oral terfenadine for treatment of the common cold. Ann Allergy. 1991;67:593-7.

46. Gwaltney JM Jr, Park J, Paul RA, Edelman D, O'Connor RR, Tumer RB. A controlled trial of clemastine fumarate in experimental rhinovirus colds [abstract H41\}. Abstracts of the 34th ICAAC. Washington, DC: American Society for Microbiology, 1994.

47. Borum P. Olsen L. Winther B, Mygind N. Ipratropium nasal spray: a new treatment for thinorrhea in the common cold. Am Rev Respir Dis. 1981;123:418-20.

48. Akerlund A, Klint T, Olen L, Rundcrantz $\mathrm{H}$. Nasal decongestant ef fect of oxymetazoline in the common cold: an objective doseresponse study in 106 patients. J Laryngol Otol. 1989;103:743-6.

49. Berkowitz RB, Connell JT, Diet $z$ AJ, Greenstein JM, Tinkelman DG. The effectiveness of the nonsedating antihistamine loratidine plus pseudoephedrine in the symptomatic management of the common cold. Ann Allergy. 1989;63:336-9.

50. Gwaltney JM Jr. Combined antiviral and antimediator treatment of Thinovirus colds. J Infect Dis. 1992:166:776-82.

51. Pinnock CB. Graham NM, Mylvaganam A, Douglas RM. Relationship between milk intake and mucus production in adult volunteers challenged with thinovirus-2. Am Rev Respir Dis. 1990; 141:352-6.

52. Tyrrell D. Barrow I, Arthur J. Local hyperthermia benefits natural and experimental common colds. BMJ. 1989;298:1280-3.

53. Macknin MI. Mathew S, Medendorp S. Effect of inhaling heated vapor in symptoms of the common cold. JAMA. 1990:264:989-91.

54. Forstall GJ. Macknin ML. Yen-Lieberman BR, Medendrop SV. Effect of inhaling heated vapor on symptoms of the common cold. JAMA. 1994;271:1109-11.

55. Farr BM, Conner EM, Betts RF, Oleske J, Minnefor $A$, Gwaltney JM Jr. Two randomized controlled trials of zinc gluconate lozenge therapy of experimentally induced rhinovirus colds. Antimirrob Agents Chemother. 1987:31:1183-7.

56. Douglas RM, Miles HB, Moore BW, Ryan P, Pinnock CB. Failure of effervescent zinc acetate lozenges to alter the course of upper respiratory tract infections in Australian adults. Antimicrob Agents Chernother. 1987;31:1263-5.

57. Godfrey JC. Sloane BC. Smith PS, Turco JN, Mercer N, Godfrey
NJ. Zinc gluconate and the common cold: a controlled clinical study. J Int Med Res. 1992;20:234-46.

58. Chalmers TC. Effects of ascorbic acid on the common cold. An evaluation of the evidence. Am J Med. 1975;58:532-6.

59. Panusarn C. Stanley ED. Dirda V, Rubenis M, Jackson GG. Prevention of ilness from rhinovirus infection by a topical interferon inducer. N Engl J Med. 1974;291:57-61.

60. Hayden FG, Gwaltney JM Jr. Intranasal interferon alpha 2 for prevention of rhinovirus infection and illness. J Infect Dis. 1983; 148:543-50.

61. Douglas RM, Moore BW, Miles HB, et al. Prophylactic efficacy of alpha 2 -interferon against rhinovirus infections in the family setting. N Engl 3 Med. 1986;314:65-70.

62. Monto AS, Schwartz SA. Albrecht JK. Ineffectiveness of postexposure prophylaxis of rhinovirus infection with low-dose intranasal alpha $2 b$ interferon in families. Antimicrob Agents Chemother. 1989;33:387-90.

63. Sperber SJ, Levine PA, Sorrentino JV, Riker DK, Hayden FG. Ineffectiveness of recombinant interferon-beta serine nasal drops for prophylaxis of natural colds. I Infect Dis. 1989;160:700-5.

64. Schwartz AR, Toyo Y. Hornick RB. Tominaga S, Gleckman RA. Evaluation of the efficacy of ascorbic acid in prophylaxis of induced rhinovirus 44 infection in man. $J$ Infect Dis. 1973:128:500-5.

65. Coulehan JL, Reisinger KS, Rogers $\mathrm{KD}$, Bradley DW. Vitamin C prophylaxis in a boarding school. N Engl J Med. 1974:290:6-10.

66. Coulehan JL, Eberhard S, Kapner L, Taylor F, Rogers K, Gary P. Vitamin $C$ and acute illness in Navaho school children. $N$ Engl $J$ Med. 1976;295:973-7.

67. Hayden GF, Hendley JO, Gwaltney JM Jr. The effect of placebo and virucidal paper handkerchiefs on viral contamination of the hand and transmission of experimental rhinoviral infection. I Infect Dis. 1985:152:403-7.

68. Dick EC, Hossain SU. Mink KA, et al. Interruption of transmission of rhinovirus colds among human volunteers using virucidal paper handkerchiefs. $J$ infect Dis. 1986;153:352-6.

69. Hayden GF, Deforest D. Hendley JO, Gwaltney JM Jr. Inactivation of rhinovirus on human fingers by virucidal activity of glutaric acid. Antimicrob Agents Chemother. 1984;26:928 9 .

70. Benchley R. How to avoid colds. In: Benchley-Or Else. New York: Harper and Brothers, 1947;164-6. 